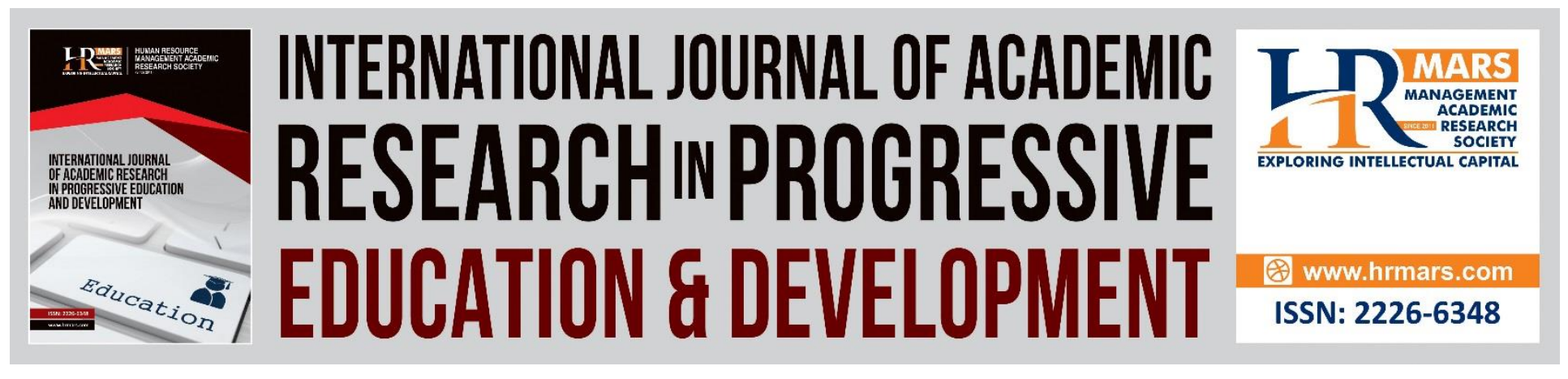

\title{
Influencing Effect of Physical Fitness Components on Football Playing Ability Among Male Players Under 14 Years
}

Khairul Sham Bin Hanapiah, Ahmad Bin Hashim, Zulakbal Bin Abd Karim

To Link this Article: http://dx.doi.org/10.6007/IJARPED/v9-i3/8086 DOI:10.6007/IJARPED/v9-i3/8086

Received: 20 June 2020, Revised: 28 July 2020, Accepted: 19 August 2020

Published Online: 25 September 2020

In-Text Citation: (Hanapiah, Hashim, \& Abd Karim, 2020)

To Cite this Article: Hanapiah, K. S. B., Hashim, A. Bin., \& Abd Karim, Z. Bin. (2020). Influencing Effect of Physical Fitness Components on Football Playing Ability Among Male Players Under 14 Years. International Journal of Academic Research in Progressive Education \& Development. 9(3), 12-25.

Copyright: (C) 2020 The Author(s)

Published by Human Resource Management Academic Research Society (www.hrmars.com)

This article is published under the Creative Commons Attribution (CC BY 4.0) license. Anyone may reproduce, distribute, translate and create derivative works of this article (for both commercial and non-commercial purposes), subject to full attribution to the original publication and authors. The full terms of this license may be seen

at: http://creativecommons.org/licences/by/4.0/legalcode

Vol. 9(3) 2020, Pg. 12 - 25

http://hrmars.com/index.php/pages/detail/IJARPED

JOURNAL HOMEPAGE

Full Terms \& Conditions of access and use can be found at http://hrmars.com/index.php/pages/detail/publication-ethics 


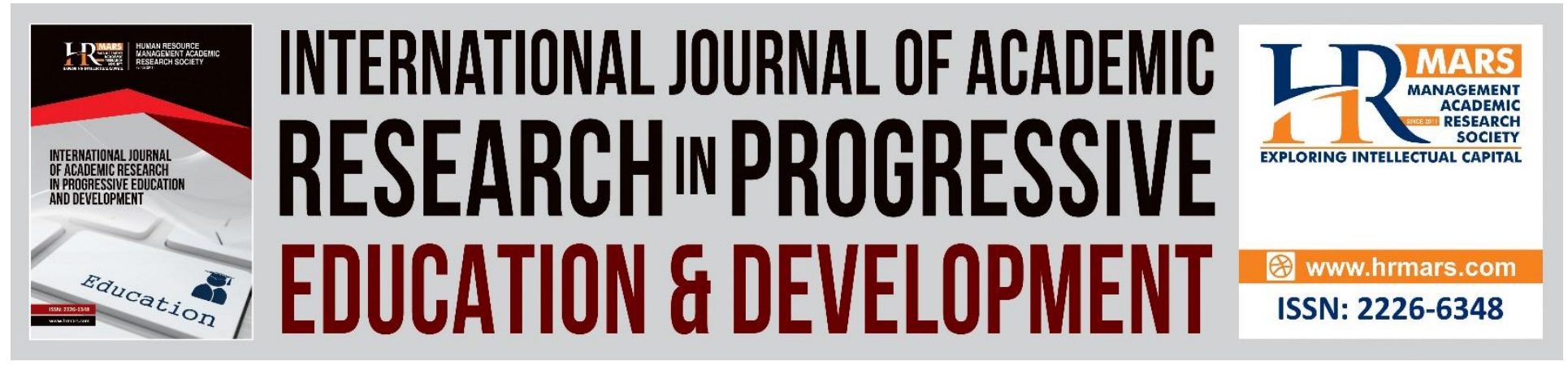

\title{
Influencing Effect of Physical Fitness Components on Football Playing Ability Among Male Players Under 14 Years
}

\section{Khairul Sham Bin Hanapiah¹, Ahmad Bin Hashim², Zulakbal Bin Abd Karim²}

${ }^{1}$ Department of Physical Education and Health, Institute of Teacher Education Temenggong Ibrahim Campus, Johor, Malaysia, ${ }^{2}$ Faculty of Sports Science and Coaching, Sultan Idris

Education University, Perak, Malaysia

Email: khairulsham@yahoo.com

\begin{abstract}
The main purpose of this study was to evaluate the influencing effect of physical fitness components on football playing ability among male players under 14 years. This study uses a cross-sectional method of survey design. A total of 208 football male players under 14 years were randomly selected from a school-based football programme in Malaysia. The data of this study were analyzed using multiple linear regression test. The findings indicate that there are nine out of 14 predictor tests of physical fitness components which are body mass index, body fat percentage, sit and reach, standing long jump, Yo-Yo intermittent recovery level $1\left(\mathrm{VO}_{2 \max }\right)$, 5 meter sprint, 30 meter sprint, T-test (left) and T-test (right) have significant influencing effect on football playing ability among male players under 14 years. The combination of these nine physical fitness component tests contributed 79.6 percent ( $R$ Square value $=.796$ ) the variance of the physical fitness component can be explained by the linear combination of scores in the football playing ability $[F(14,193)=53.649, p<.000]$. In conclusion, nine physical fitness component predictor tests can be used as a physical fitness standard test battery for male football players under 14 years. The implication of study showed that the use of nine physical fitness component predictor tests can ensure the selected football male player talent under 14 years are those who really have a high level of physical fitness to compete at international level. Keywords: Physical Fitness, Playing Ability, Football.
\end{abstract}

\section{Introduction}

In the actual 90 minutes of a game, a football player will need to do various movements such as walking, jogging, running, and sprinting, and the speed intensity that require a high level of physical fitness (Salvo, Pigozzi, Gonzalez-Haro, Laughlin, \& Witt, 2013). In the knockout stage, if both teams have the same number of goals in the original 90 minutes, an additional 30 minutes will be held to determine the winner (Tumilty, 1993). The average total distance traveled by a 
player (excluding goalkeepers) in a game is about 10 to 12 kilometers which includes more than 1,000 different activities which changes in the type or level of activity that occurs every 6 seconds (Reilly, 1997). Several previous studies have been conducted to determine specific physical fitness demands during matches and the level of physical fitness performance required to achieve success in competitive football (Keller, Raynor, Bruce, \& Iredale, 2018; Marques et al., 2016; Trecroci, Milanovic, Frontini, laia, \& Alberti, 2018).

Physical fitness is an individual's ability to perform optimal physical activities (Ortega, Ruiz, Castillo, \& Sjostrom, 2008) and can be defined in terms of performance and health (Artero et al., 2011). According to Ortega, Ruiz, Castillo, and Sjostrom (2008), physical fitness is an integrated measure of body functions (skeletomuscular, cardiorespiratory, hematocirculatory, psychoneurological and endocrine-metabolic) which involved in daily physical work and/or physical exercise. Physical fitness components such as endurance, speed, agility, strength, power and flexibility are the factors that influence the overall level of performance in football game (Murr, Raabe, \& Honer, 2017; Turner et al., 2011).

Football requires repeated powerful movements like kicking, sprinting, tackling, and jumping which largely depending on the ability to use the greatest force (maximum strength) (Peterson, Alvar, \& Rhea, 2006; Turner et al., 2011). Football involves from low to high intensity intermittent activities that require players to have the ability of aerobic and anaerobic systems for energy transmission while playing (Reilly et al., 2000; Williams \& Reilly, 2000). This is because a player will perform physical movements such as (1) standing; (2) walking; (3) low-intensity running, encompassing jogging, low-speed running and backward running; and (4) high-intensity running, consisting of moderate-speed running, high-speed running and sprinting for 90 minutes (Mohr, Krustrup, \& Bangsbo, 2003; Saward, Morris, Nevill, Nevill, \& Sunderland, 2015). Bangsbo, Norregaard, and Thorso (1991) have reported that 90 percent of physical activity is contributed from an aerobic energy system with high-intensity activity for seven minutes. Therefore, a high level of maximum oxygen intake $\left(\mathrm{VO}_{2 \mathrm{max}}\right)$ is a necessity for a player in a competitive matches. It is clear that aerobic capacity $\left(\mathrm{VO}_{2 \max }\right)$ is a relevant indicator to determine the maximum level of oxygen that can be taken and used by the body during a game.

Since 1988, one of the most widely used physical fitness test batteries across Europe for testing children and adolescents aged six to 18 years is Eurofit (Cvejic, Pejovic, \& Ostojic, 2013; Tomkinson et al., 2017). Eurofit includes a range of health- and performance-related fitness tests, consisting of (1) field tests measuring balance, cardio-respiratory (aerobic) endurance, muscular endurance (abdominal and upper body), flexibility, power, speed, speed agility and strength; (2) anthropometric tests measuring height, mass and skinfold thicknesses at various sites, and (3) age and sex identification data (Tomkinson, Olds, \& Borms, 2007). Eurofit test battery has high value of reliability and criterion validity for measuring an individual's physical fitness performance at the stage of childhood to adolescence (Artero et al., 2011; Castro-Pinero et al., 2010; Tomkinson et al., 2017, 2007). According to Tomkinson et al., (2017), Eurofit is a very useful field test battery because it is convenient and economic, practical to be carried out on large groups of participants such as schools and clubs, requires minimal equipment and testers, and suitable for 
body mass testing. Some of the Eurofit test battery commonly used by previous researchers to measure the level of physical fitness of football players aged 12 to 16 years are body mass index and body fat percentage (body composition), sit and reach test (flexibility), flamingo balance test (dynamic balance), standing long jump test (explosive leg power) and handgrip strength test (maximum isometric strength)(Deprez et al., 2015; Fransen, Bennett, et al., 2017; Philippaerts et al., 2006; Pion et al., 2014; Vaeyens et al., 2006).

In addition, the Bruininks-Oseretsky test of motor proficiency, second edition (BOT-2; Bruininks \& Bruininks, 2005) is a standard norm test used by physical therapists and occupational therapists in school and clinical practice settings to measure fine and gross motor skills of children and adolescents aged four to 21 years (Deitz, Kartin, \& Kopp, 2007). The Bruininks-Oseretsky test (BOT-2) of motor proficiency, second edition is used by practitioners (occupational therapists, physical therapists and adapted Physical Education teachers) and researchers to support the diagnosis of motor disability, screening children and adolescents who may have motor impairments, assist with program placement or adjustment and evaluation of motor interventions (Deitz et al., 2007). Several previous studies have reported that knee push-ups and sit-ups tests (upper body strength endurance) using test procedures (BOT-2; Bruininks \& Bruininks, 2005) have been widely used for the purpose of identifying talent in sports (Opstoel et al., 2015; Pion et al., 2014; Vandorpe et al., 2012).

Next, some past studies have found that Yo-Yo intermittent recovery level 1 test (aerobic capacity), 5 meter and 30 meter sprint test (acceleration and speed) and T-test (speed and agility) was used as a field test to measure football-specific fitness performance (Bangsbo, laia, \& Krustrup, 2008; Deprez et al., 2015; Hulse et al., 2013; Philippaerts et al., 2006; Pion et al., 2014; Rommers et al., 2018; Svensson \& Drust, 2005; Turner et al., 2011; Vaeyens et al., 2006). Thus, the specific objective of this study is to determine the influencing effect of physical fitness components on the football playing ability among male players under 14 years. Researchers want to identify whether (1) body composition, (2) flexibility, (3) dynamic balance, (4) maximum isometric strength, (5) speed and agility, (6) upper body strength endurance, (7) power, (8) aerobic capacity, and (9) acceleration and speed contribute to the football playing ability among male players under 14 years.

\section{Methodology}

Methodology of this study focuses on the research design, sample, instrument and data analysis procedures.

\section{Research Design}

This study uses a cross-sectional method of survey design (Ary, Jacobs, Sorensen, \& Walker, 2014).

\section{Sample}

The participants involved in this study are male student-athletes under 14 years from a schoolbased football programme in Malaysia. Sample size selection for this study is based on Power 
Tables for Effect Size from Cohen (1988), with the sampling power value of .80, the effect of size (d) .30 , the power of .80 and the significant level at $\alpha=.05$. Based on the formula, the sample size should be 175 people. However, the researchers used a sample size of 208 after considering the absence or mortality factor (Tuckman \& Waheed, 1981) that could possibly happen. All study samples were randomly selected.

\section{Instrument}

The instrument consists of physical fitness test which was measured using a partially Eurofit test battery (Council of Europe, 1988), Bruininks-Oseretsky test (BOT-2) of motor proficiency, second edition (BOT-2; Bruininks \& Bruininks, 2005) and football-specific fitness test (Bangsbo et al., 2008; Deprez et al., 2015; Pion et al., 2014; Vandendriessche et al., 2012) which frequently used by previous researchers to identify talent among football adolescent male players.

Body Composition. Body composition is measured based on body mass index and body fat percentage. Height and weight values are used to calculate body mass index (BMI = weight / height $^{2}$ ) (Malina, 2003). The body fat percentage (BF\%) was obtained using the formula provided by Deurenberg, Weststrate, and Seidell (1991) BF\% $=1.51 \times$ BMI $-0.70 \times$ age -3.6 x gender +1.4 (male = 1).

Flexibility. Flexibility is measured using sit and reach test according to guidelines (Council of Europe, 1988) $(0.5 \mathrm{~cm})$. Sit and reach test has adequate validity and reliability values between .60 to .73 and .70 to .98 respectively, measured in children and adolescents aged 4 to 18 years (Opstoel et al., 2015).

Dynamic Balance. Flamingo balance test (Council of Europe, 1988) is performed to measure the body's ability to balance in a static state. Players balancing on one foot for 60 seconds while standing at the preferred foot on the wood beam balance (length $50 \mathrm{~cm}$, height $5 \mathrm{~cm}$ and width $3 \mathrm{~cm}$ ). Scores are calculated based on the number of balance losses within 60 seconds.

Maximum Isometric Strength. Handgrip strength test are used to measure the maximum isometric strength of the hand and forearm muscles (Council of Europe, 1988). Handgrip strength test is measured using a handgrip dynamometer.

Upper Body Strength Endurance. Upper body strength endurance are measured using knee push-ups and sit-ups tests according to the procedure by Bruininks-Oseretsky test of motor proficiency, second edition (BOT-2; Bruininks \& Bruininks, 2005) which requires players to perform as many repetitions as possible in 30 seconds (Pion et al., 2014).

Power. Standing long jump test was used to measure the explosive power of the legs. The subject attempts to jump as far as possible, landing on both feet without falling backwards. The longest distance jumped is counted as the test score. 
Aerobic Capacity. Aerobic capacity was measured using Yo-Yo intermittent recovery level 1 test (YYIR1) performed in the field by wearing football shoes for 10 - 20 minutes according to the procedure by Krustrup et al., (2003). The Yo-Yo intermittent recovery level 1 test consists of repeated $2 \times 20-\mathrm{m}$ runs back and forth between the starting, turning, and finishing line at a progressively increased speed controlled by audio bleeps from a tape recorder. Between each running bout, the subjects have a 10-s active rest period, consisting of $2 \times 5 \mathrm{~m}$ of jogging. When the subjects twice have failed to reach the finishing line in time, the distance covered is recorded and represents the test result. In the present study, we used the Yo-Yo intermittent recovery test, level 1 , which consist of 4 running bouts at $10-13 \mathrm{~km} \cdot \mathrm{h}-{ }^{1}(0-160 \mathrm{~m})$ and another 7 runs at $13.5-$ $14 \mathrm{~km} \cdot \mathrm{h}-{ }^{1}(160-440 \mathrm{~m})$, whereafter it continues with stepwise $0.5 \mathrm{~km} \cdot \mathrm{h}-{ }^{1}$ speed increments after every 8 running bouts (i.e., after 760, 1080, 1400, 1720 m, etc.) until exhaustion. The estimated value of maximum oxygen intake $\left(\mathrm{VO}_{2 \max }\right)$ is calculated through a non-gender specific formula proposed by Bangsbo et al., (2008) which is $\mathrm{VO}_{2 \max }\left(\mathrm{mL} / \mathrm{min}^{-1} / \mathrm{kg}^{-1}\right)=$ distance YYIR1 (meters) $\mathrm{x}$ $0.0084+36.4$ and the YYIR1 test protocol table (Castagna et al., 2006).

Acceleration and Speed. Acceleration and speed performance are measured through 5 meter and 30 meter sprint test. Split times were recorded at 5 meter and 30 meter, enabling the assessment of starting speed, the capacity to accelerate, and running speed (Deprez et al., 2015; Pion et al., 2014).

Speed and Agility. To assess speed and agility, participants performed a T-test according to the procedure by Vandendriessche et al., (2012). The athletes ran 5 meter straight, turned $90^{\circ}$ and ran 5 meter towards the next turn of $180^{\circ}$, ran 10 meter towards the third turn $\left(180^{\circ}\right)$, ran a further 5 meter towards the last turn of $90^{\circ}$, ultimately finishing at the initial starting point. The T-test was performed in both directions with the participants turning to the left at the first attempt.

Football Playing Ability. Football playing ability refers to a visual analog scale adapted from Lovell et al., (2017) and Sieghartsleitner et al., (2019). Visual analog scale have been used by coaches to assess football playing ability comprehensively which includes physical, technical, tactical and psychological aspects. The football playing ability score is calculated based on the average score obtained from two qualified coaches. Scores will be rated between 0 and 100 . The highest score is 100 and the lowest score is 0 .

\section{Data Analysis Procedures}

Data obtained from physical fitness tests were analyzed using SPSS 20.0 (Statiscal Package for Social Science 20.0) software. Multiple linear regression was used to identify the extent of influencing effects of the significant components of physical fitness on the football playing ability among male players under 14 years. Temporarily, assumptions test of multivariate data analysis (MVA) were tested encompasses normality, linearity and multicollinearity (Pallant, 2010). These assumptions need to be met to ensure that least square measures are unbiased. 
In multiple linear regression, the independent variable $(X)$ is named as the predictor variable, while the dependent variable $(Y)$ is named as the criterion variable. In multiple linear regression, all independent variables or predictors are included simultaneously in one equation. The multiple linear regression equation of physical fitness components is shown as below:

$\mathrm{Y}=b_{1} \mathrm{X}_{1}+b_{2} \mathrm{X}_{2}+b_{3} \mathrm{X}_{3}+b_{4} \mathrm{X}_{4}+b_{5} \mathrm{X}_{5}+b_{6} \mathrm{X}_{6}+b_{7} \mathrm{X}_{7}+b_{8} \mathrm{X}_{8}+b_{9} \mathrm{X}_{9}+b_{10} \mathrm{X}_{10}+b_{11} \mathrm{X}_{11}+b_{12} \mathrm{X}_{12}+$ $b_{13} \mathrm{X}_{13}+b_{14} \mathrm{X}_{14}+a$

In the above equation, $Y$ is the value of the criterion variable predicted by the predictor variable value $\mathrm{X}_{1}, \mathrm{X}_{2}, \mathrm{X}_{3}, \mathrm{X}_{4}, \mathrm{X}_{5}, \mathrm{X}_{6}, \mathrm{X}_{7}, \mathrm{X}_{8}, \mathrm{X}_{9}, \mathrm{X}_{10}, \mathrm{X}_{11}, \mathrm{X}_{12}, \mathrm{X}_{13}$, and $\mathrm{X}_{14}, b_{1}, b_{2}, b_{3}, b_{4}, b_{5}, b_{6}, b_{7}, b_{8}, b_{9}, b_{10}, b_{11}$, $b_{12}, b_{13}$, and $b_{14}$ is a regression coefficient for each predictor variable, while $a$ is a regression constant.

\section{Results}

The results of multiple linear regression analysis were used to identify the significant influencing effect of physical fitness components on the football playing ability among 14-year-old male players. Fourteen independent variables were the score of the body mass index, body fat percentage, sit and reach, handgrip strength (right), handgrip (left), standing long jump, knee push-ups (BOT-2), sit-ups (BOT-2), flamingo balance, Yo-Yo intermittent recovery level 1 $\left(\mathrm{VO}_{2 \text { max }}\right), 5$ meter sprint, 30 meter sprint, T-test (left) and T-test (right). The dependent variable is the football playing ability.

Table 1 below shows that all 14 predictor tests of physical fitness component have a significant influencing effect on the football playing ability, $R$ Squared $=.796, F(14,193)=53.649$, $p=.000$. The results of the analysis indicated that there is a significant influencing effect of physical fitness components on the football playing ability. Correlation analysis of multiple linear regression coefficient was $R=.892$. This means 79.6 percent ( $R$ Square value $=.796$ ) variance of physical fitness components (body mass index, body fat percentage, sit and reach, handgrip strength (right), handgrip strenght (left), standing long jump, knee push-ups (BOT-2), sit-ups (BOT-2), flamingo balance, Yo-Yo intermittent recovery level $1\left(\mathrm{VO}_{2 \max }\right), 5$ meter sprint, 30 meter sprint, T-test (left) and T-test (right)) can be explained by the linear combination of scores in the football playing ability. The regression equation based on B weights is as follows: -

Predicted Football Playing Ability $=+.309$ Body Mass Index +.312 Body Fat Percentage -.069 Sit and Reach +.040 Handgrip Strength (Right) +.052 Handgrip Strength (Left) +.050 Standing Long Jump +.000 Knee Push-Ups (BOT-2) -.004 Sit-Ups (BOT-2) -.023 Flamingo Balance +.129 Yo-Yo Intermittent Recovery Level 1 ( $\left.\mathrm{VO}_{2 \max }\right)$ -9.382 5 Meter Sprint -14.177 30 Meter Sprint -1.379 T-Test (Left) -1.228 T-Test (Right) +163.010 
INTERNATIONAL JOURNAL OF ACADEMIC RESEARCH IN PROGRESSIVE EDUCATION AND

DEVELOPMENT

Vol. 9, No. 3, 2020, E-ISSN: 2226-6348 @ 2020 HRMARS

Table 1

Results of Multiple Linear Regression Test for Physical Fitness Components

Model Summary

\begin{tabular}{ccccc}
\hline Model & R & R Square & Adjusted R Square & Std. Error of the Estimate \\
\hline 1 & $.892^{\mathrm{a}}$ & .796 & .781 & 1.59172 \\
\hline
\end{tabular}

a. Predictors: (Constant), T-Test (Right), Standing Long Jump, Knee Push-Ups (BOT-2), Flamingo Balance, Handgrip (Left), Sit and Reach, Body Fat Percentage, Sit-Ups (BOT-2), Yo-Yo Intermittent Recovery Level 1 ( $\mathrm{VO}_{2 \mathrm{max}}$ ), Handgrip (Right), 5 Meter Sprint, Body Mass Index, 30 Meter Sprint, T-Test (Left)

b. Dependent Variable: Football Playing Ability

\section{ANOVA $^{\mathrm{a}}$}

\begin{tabular}{llccccc}
\hline \multicolumn{1}{c}{ Model } & Sum of Squares & df & Mean Square & $F$ & Sig. \\
\hline \multirow{2}{*}{1} & Regression & 1902.938 & 14 & 135.924 & 53.649 & $.000^{\mathrm{b}}$ \\
\cline { 2 - 6 } & Residual & 488.980 & 193 & 2.534 & & \\
\cline { 2 - 6 } & Total & 2391.918 & 207 & & & \\
\hline
\end{tabular}

a. Dependent Variable: Football Playing Ability

b. Predictors: (Constant), T-Test (Right), Standing Long Jump, Knee Push-Ups (BOT-2), Flamingo Balance, Handgrip (Left), Sit and Reach, Body Fat Percentage, Sit-Ups (BOT-2), Yo-Yo Intermittent Recovery Level 1 ( $\left.\mathrm{VO}_{2 \mathrm{max}}\right)$, Handgrip (Right), 5 Meter Sprint, Body Mass Index, 30 Meter Sprint, T-Test (Left)

Coefficients $^{a}$

\begin{tabular}{|c|c|c|c|c|c|c|c|c|}
\hline \multirow[t]{2}{*}{ Model } & \multicolumn{2}{|c|}{$\begin{array}{l}\text { Unstandardized } \\
\text { Coefficients }\end{array}$} & \multirow{2}{*}{$\begin{array}{c}\text { Standardized } \\
\text { Coefficients }\end{array}$} & \multirow[t]{2}{*}{$\mathrm{t}$} & \multirow[t]{2}{*}{ Sig. } & \multicolumn{3}{|c|}{ Correlations } \\
\hline & B & $\begin{array}{l}\text { Std. } \\
\text { Error }\end{array}$ & & & & $\begin{array}{l}\text { Zero- } \\
\text { order }\end{array}$ & Partial & Part \\
\hline (Constant) & 163.010 & 10.895 & & 14.963 & .000 & & & \\
\hline Body Mass & .309 & .128 & .102 & 2.413 & .017 & .554 & .171 & .079 \\
\hline \multicolumn{9}{|l|}{ Index } \\
\hline Body Fat & .312 & .100 & .119 & 3.122 & .002 & .403 & .219 & .102 \\
\hline \multicolumn{9}{|l|}{ Percentage } \\
\hline Sit and Reach & -.069 & .020 & -.122 & -3.533 & .001 & -.064 & -.246 & -.115 \\
\hline 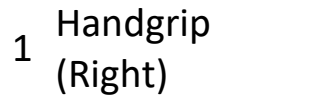 & .040 & .032 & .044 & 1.245 & .215 & .310 & .089 & .041 \\
\hline Handgrip (Left) & .052 & .032 & .056 & 1.644 & .102 & .294 & .118 & .054 \\
\hline $\begin{array}{l}\text { Standing Long } \\
\text { Jump }\end{array}$ & .050 & .018 & .098 & 2.826 & .005 & .300 & .199 & .092 \\
\hline $\begin{array}{l}\text { Knee Push-Ups } \\
\text { (BOT-2) }\end{array}$ & .000 & .030 & -.001 & -.015 & .988 & .142 & -.001 & .000 \\
\hline Sit-Ups (BOT-2) & -.004 & .029 & -.004 & -.121 & .904 & .191 & -.009 & -.004 \\
\hline
\end{tabular}


INTERNATIONAL JOURNAL OF ACADEMIC RESEARCH IN PROGRESSIVE EDUCATION AND DEVELOPMENT

Vol. 9, No. 3, 2020, E-ISSN: 2226-6348 @ 2020 HRMARS

\begin{tabular}{lcccccccc}
$\begin{array}{l}\text { Flamingo } \\
\text { Balance }\end{array}$ & -.023 & .047 & -.016 & -.481 & .631 & -.120 & -.035 & -.016 \\
$\begin{array}{l}\text { Yo-Yo } \\
\text { Intermittent }\end{array}$ & .129 & .043 & .109 & 3.020 & .003 & .407 & .212 & .098 \\
$\begin{array}{l}\text { Recovery Level } \\
\text { (YYIR1) }\end{array}$ & & & & & & & & \\
$\begin{array}{l}\text { (VO)max) } \\
\text { S Meter Sprint }\end{array}$ & -9.382 & 2.306 & -.160 & -4.069 & .000 & -.581 & -.281 & -.132 \\
$\begin{array}{l}\text { SOMeter } \\
\text { Sprint }\end{array}$ & -14.177 & 2.121 & -.290 & -6.683 & .000 & -.718 & -.433 & -.217 \\
T-Test (Left) & -1.379 & .285 & -.218 & -4.838 & .000 & -.656 & -.329 & -.157 \\
T-Test (Right) & -1.228 & .235 & -.224 & -5.234 & .000 & -.599 & -.353 & -.170 \\
\hline
\end{tabular}

a. Dependent Variable: Football Playing Ability

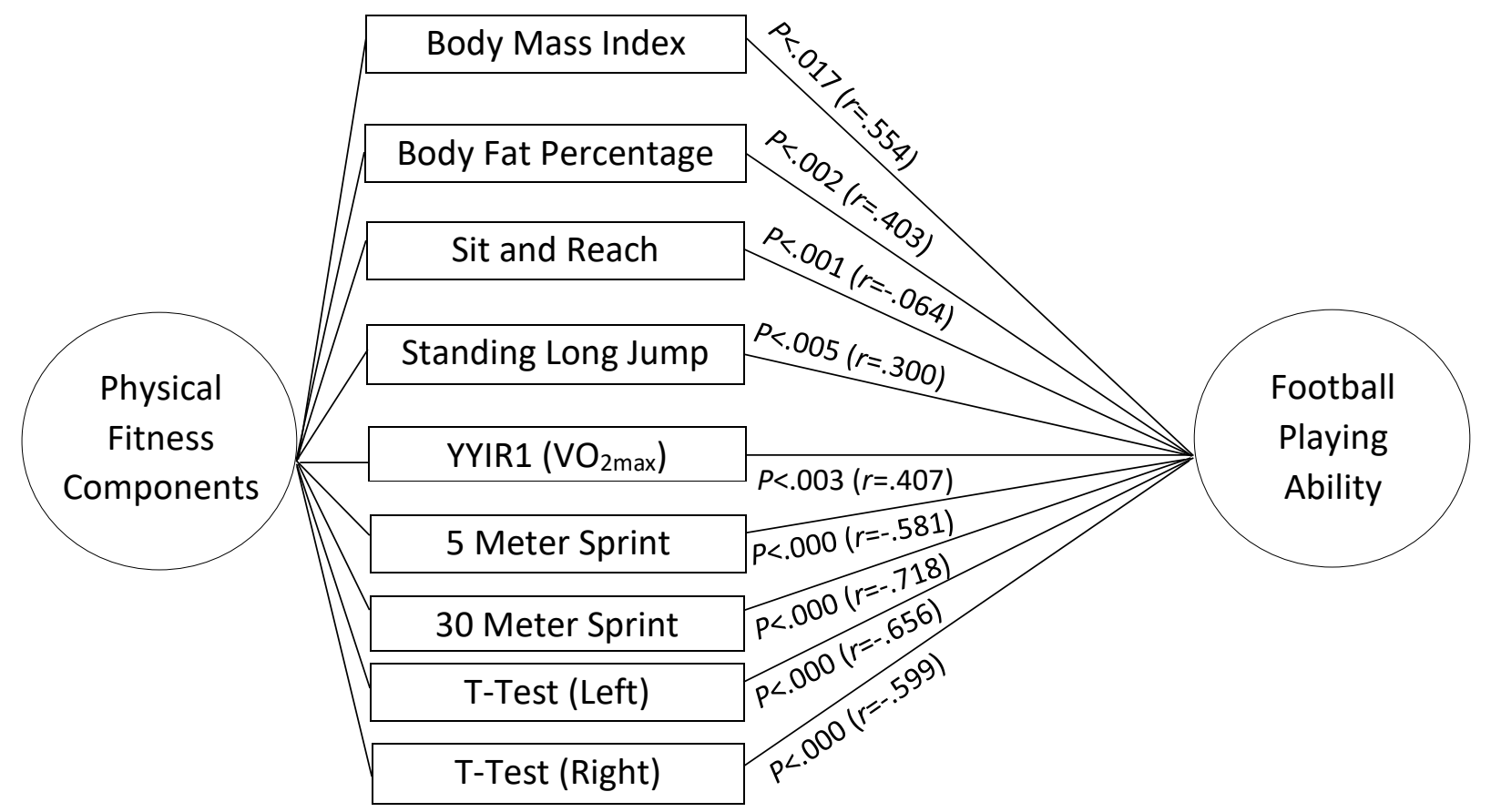

Figure 1. Correlation of Physical Fitness Components Towards Football Playing Ability

\section{Discussion}

The physical fitness component is a factor influencing the overall level of performance in the game of football (Murr et al., 2017). Most of previous studies evaluated the similar physical fitness performance such as body composition, flexibility, balance, power, speed, agility, cardiovascular endurance, muscle endurance and muscle strength for children and adolescents aged six to 18 years (Bianco et al., 2015; Cattuzzo et al., 2016; Kolimechkov, 2017).

The results of this study indicate that body composition, flexibility, power, speed and agility, aerobic capacity, acceleration and speed are significant predictors on the football playing 
ability. The results of physical fitness analysis show that body mass index, body fat percentage, sit and reach, standing long jump, Yo-Yo intermittent recovery level 1 ( $\left.\mathrm{VO}_{2 \max }\right), 5$ meter sprint, 30 meter sprint, T-test (left) and T-test (right) have a significant influencing effect on the football playing ability. These findings are supported by the evidences of previous studies where these physical fitness tests have been proven as valid and reliable tool for evaluating the performance of young male football players (Deprez et al., 2015; Pion et al., 2014; Vaeyens et al., 2006; Vandendriessche et al., 2012).

This finding is consistent with football expertise prediction model by Williams and Reilly (2000) which states that the physical fitness is an important indicator of physical and physiological demands during competitive games. There is evidence that the rate of work in modern football games requires young players to have high physical fitness capabilities (Bangsbo, 2014; Dodd \& Newans, 2018). Therefore, physical fitness tests are considered crucial by coaches $(97 \%)$, fitness coaches $(94 \%)$ and players $(83 \%)$ to monitor performance progress and analyze the training effects (Hulse et al., 2013).

\section{Conclusion and Recommendations}

It is important for a young players to have physical fitness to play at international level. To achieve optimal performance in competitive matches, a young players needs to have a combination of physical fitness components such as body composition, flexibility, power, speed and agility, aerobic capacity, acceleration and speed. Furthermore, the components of physical fitness are interrelated with the motor competence capabilies of a young players (Fransen et al., 2017). This study has shown that body mass index, body fat percentage, sit and reach, standing long jump, Yo-Yo intermittent recovery level $1\left(\mathrm{VO}_{2 \max }\right), 5$ meter sprint, 30 meter sprint, T-test (left) and T-test (right) has the significant influencing effect on the football playing ability among male players under 14 years.

As the finding of this study is obtained through a cross-sectional approach, the researchers suggest that further longitudinal studies be conducted by assessing the development of the same players from age of 13 to 15 years to ensure that only players with high levels of physical fitness will be maintained within a single talent group as recommended by the Developmental Model of Sport Participation (Cote, Baker, \& Abernethy, 2007). Future researchers may identify changes in characteristics and behaviors as well as assess the reasons for those changes.

\section{Corresponding Author \\ Khairul Sham Bin Hanapiah}

Lecturer, Department of Physical Education and Health, Institute of Teacher Education Temenggong Ibrahim Campus, Johor, Malaysia

Email: khairulsham@yahoo.com 
INTERNATIONAL JOURNAL OF ACADEMIC RESEARCH IN PROGRESSIVE EDUCATION AND

DEVELOPMENT

Vol. 9, No. 3, 2020, E-ISSN: $2226-6348$ @ 2020 HRMARS

\section{References}

Artero, E. G., Espana-Romero, V., Castro-Pinero, J., Ortega, F. B., Suni, J., Castillo-Garzon, M. J., \& Ruiz, J. R. (2011). Reliability of field-based fitness tests in youth. International Journal of Sports Medicine, 32(3), 159-169.

Ary, D., Jacobs, L. C., Sorensen, C., \& Walker, D. A. (2014). Introduction to research in education (9th ed.). United States: Wadsworth Cengage Learning.

Bangsbo, J., Norregaard, L., \& Thorso, F. (1991). Activity profile of competition soccer. Canadian Journal of Sport Sciences, 16(2), 110-116.

Bangsbo, J., laia, F. M., \& Krustrup, P. (2008). The Yo-Yo intermittent recovery test: A useful tool for evaluation of physical performance in intermittent sports. Sports Medicine, 38(1), 3751.

Bangsbo, J. (2014). Physiological demands of football. Sports Science Exchange, 27(125), 1-6.

Bianco, A., Jemni, M., Thomas, E., Patti, A., Paoli, A., Ramos Roque, J., ... Tabacchi, G. (2015). A systematic review to determine reliability and usefulness of the field-based test batteries for the assessment of physical fitness in adolescents - The ASSO Project. In International Journal of Occupational Medicine and Environmental Health, 28(3), 445-478.

Bruininks, R., \& Bruininks, B. (2005). BOT-2: Bruininks-Oseretsky tests of motor proficiency (2nd ed.). Minneapolis: MN: NCS Pearson.

Castagna, C., Impellizzeri, F. M., Chamari, K., Carlomagno, D., \& Rampinini, E. (2006). Aerobic fitness and Yo-Yo continuous and intermittent tests performances in soccer players. Journal of Strength and Conditioning Research, 20(2), 320-325.

Castro-Pinero, J., Artero, E. G., Espana-Romero, V., Ortega, F. B., Sjostrom, M., Suni, J., \& Ruiz, J. R. (2010). Criterion-related validity of field-based muscular fitness tests in youth. British Journal of Sports Medicine, 44, 934-943.

Cattuzzo, M. T., Dos Santos Henrique, R., Re, A. H. N., De Oliveira, I. S., Melo, B. M., De Sousa Moura, M., ... Stodden, D. (2016). Motor competence and health related physical fitness in youth: A systematic review. Journal of Science and Medicine in Sport, 19(2), 123-129.

Cohen, J. (1988). Statistical power analysis for the behavioral sciences (2nd ed.). United States of America: Lawrence Erlbaum Associates.

Cote, J., Baker, J., \& Abernethy, B. (2007). Practice and play in the development of sport expertise. In Handbook of sport psychology (3rd ed., pp. 184-202). Hoboken, NJ: Wiley \& Sons Inc.

Council of Europe. (1988). Eurofit: Handbook for the EUROFIT tests of physical fitness. Rome: Secretariat of the Committee for the Development of Sport within the Council of Europe.

Cvejic, D., Pejovic, T., \& Ostojic, S. (2013). Assessment of Physical Fitness in Children and Adolescents. Physical Education and Sport, 11(2), 135-145.

Deitz, J. C., Kartin, D., \& Kopp, K. (2007). Review of the Bruininks-Oseretsky Test of motor proficiency, second edition (BOT-2). Physical \& Occupational Therapy In Pediatrics, 27(4), 87-102.

Deprez, D., Buchheit, M., Fransen, J., Pion, J., Lenoir, M., Philippaerts, R. M., \& Vaeyens, R. (2015). A longitudinal study investigating the stability of anthropometry and soccer- specific endurance in pubertal high-level youth soccer players. Journal of Sports Science and Medicine, 14(2), 418-426.

Deprez, D., Fransen, J., Boone, J., Lenoir, M., Philippaerts, R., \& Vaeyens, R. (2015). Characteristics 
of high-level youth soccer players: Variation by playing position playing position. Journal of Sports Sciences, 33(3), 243-254.

Deprez, D. N., Fransen, J., Lenoir, M., Philippaerts, R. M., \& Vaeyens, R. (2015). A retrospective study on anthropometrical, physical fitness, and motor coordination characteristics that influence dropout, contract status, and first- team playing time in high-level soccer players aged eight to eighteen years. Journal of Strength and Conditioning Research, 29(6), 16921704.

Deurenberg, P., Weststrate, J. A., \& Seidell, J. C. (1991). Body mass index as a measure of body fatness: Age- and sex- specific prediction formulas. British Journal of Nutrition, 65, 105-114.

Dodd, K. D., \& Newans, T. J. (2018). Talent identification for soccer: Physiological aspects. Journal of Science and Medicine in Sport, 21(10), 1073-1078.

Fransen, J., Bennett, K. J., Woods, C. T., French-Collier, N., Deprez, D., Vaeyens, R., \& Lenoir, M. (2017). Modelling age-related changes in motor competence and physical fitness in highlevel youth soccer players: Implications for talent identification and development. Science and Medicine in Football, 1(3), 203-208.

Hulse, M. A., Morris, J. G., Hawkins, R. D., Hodson, A., Nevill, A., \& Nevill, M. E. (2013). A field-test battery for elite, young soccer players. International Journal of Sports Medicine, 34(4), 302311.

Keller, B. S., Raynor, A. J., Bruce, L., \& Iredale, F. (2018). Physical and anthropometrical attributes of Australian youth soccer players. International Journal of Sports Science \& Coaching, 13(5), 787-793.

Kolimechkov, S. (2017). Physical fitness assessment in children and adolescents: A systematic review. European Journal of Physical Education and Sport Science, 3(4), 65-79.

Krustrup, P., Mohr, M., Amstrup, T., Rysgaard, T., Johansen, J., Steensberg, A., ... Bangsbo, J. (2003). The Yo-Yo intermittent recovery test: Physiological response, reliability, and validity. Medicine and Science in Sports and Exercise, 35, 697-705.

Lovell, T. W. J., Bocking, C. J., Fransen, J., \& Coutts, A. J. (2017). A multidimensional approach to factors influencing playing level and position in a school-based soccer programme. Science and Medicine in Football, 2(3), 237-245.

Malina, R. M. (2003). Growth and maturity status of young soccer players. In Thomas Reilly \& A. M. Williams (Eds.), Science and Soccer (2nd ed., pp. 287-306). New York: Taylor \& Francis Group.

Marques, C., Izquierdo, M., Gabbett, T. J., Travassos, B., Branquinho, L., \& Tillaar, R. Van Den. (2016). Physical fitness profile of competitive young soccer players: Determination of positional differences. International Journal of Sports Science \& Coaching, 11(5), 693-701.

Matthys, S. P. J., Vaeyens, R., Fransen, J., Deprez, D., Pion, J., Vandendriessche, J., ... Philippaerts, R. (2013). A longitudinal study of multidimensional performance characteristics related to physical capacities in youth handball. Journal of Sports Sciences, 31(3), 325-334.

Mohr, M., Krustrup, P., \& Bangsbo, J. (2003). Match performance of high-standard soccer players with special reference to development of fatigue. Journal of Sports Sciences, 21(7), 519-528.

Murr, D., Raabe, J., \& Honer, O. (2017). The prognostic value of physiological and physical characteristics in youth soccer: A systematic review. European Journal of Sport Science, 18(1), 62-74. 
Opstoel, K., Pion, J., Elferink-Gemser, M., Hartman, E., Willemse, B., Philippaerts, R., ... Lenoir, M. (2015). Anthropometric characteristics, physical fitness and motor coordination of 9 to 11 year old children participating in a wide range of sports. PLOS ONE, 10(5), 1-16.

Ortega, F. B., Ruiz, J. R., Castillo, M. J., \& Sjostrom, M. (2008). Physical fitness in childhood and adolescence: A powerful marker of health. International Journal of Obesity, 32(1), 1-11.

Pallant, J. (2010). SPSS survival manual: a step by step guide to data analysis using SPSS (4th ed.). Maidenhead: Open University Press.

Peterson, M. D., Alvar, B. A., \& Rhea, M. R. (2006). The contribution of maximal force production to explosive movement among young collegiate athletes. Journal of Strength and Conditioning Research, 20(4), 867-873.

Philippaerts, R. M., Vaeyens, R., Janssens, M., Van Renterghem, B., Matthys, D., Craen, R., ... Malina, R. M. (2006). The relationship between peak height velocity and physical performance in youth soccer players. Journal of Sports Sciences, 24(3), 221-230.

Pion, J., Segers, V., Fransen, J., Debuyck, G., Deprez, D., Haerens, L., ... Lenoir, M. (2014). Generic anthropometric and performance characteristics among elite adolescent boys in nine different sports. European Journal of Sport Science, 15(5), 357-366.

Reilly, T. (1997). Energetics of high-intensity exercise (soccer) with particular reference to fatigue. Journal of Sports Sciences, 15(3), 257-263.

Reilly, T., Bangsbo, J., Franks, A., Reilly, T., Bangsbo, J., \& Franks, A. (2000). Anthropometric and physiological predispositions for elite soccer. Journal of Sports Sciences, 18(9), 669-683.

Rommers, N., Mostaert, M., Goossens, L., Vaeyens, R., Witvrouw, E., Lenoir, M., \& D’Hondt, E. (2018). Age and maturity related differences in motor coordination among male elite youth soccer players. Journal of Sports Sciences, 37(2), 196-203.

Salvo, V. Di, Pigozzi, F., Gonzalez-Haro, C., Laughlin, M. S., \& Witt, J. K. De. (2013). Match performance comparison in top English soccer leagues. International Journal of Sports Medicine, 34(6), 526-532.

Saward, C., Morris, J. G., Nevill, M. E., Nevill, A. M., \& Sunderland, C. (2015). Longitudinal development of match-running performance in elite male youth soccer players. Scandinavian Journal of Medicine and Science in Sports, 26(8), 933-942.

Sieghartsleitner, R., Zuber, C., Zibung, M., \& Conzelmann, A. (2019). Science or coaches' eye? Both! Beneficial collaboration of multidimensional measurements and coach assessments for efficient talent selection in elite youth football. Journal of Sports Science and Medicine, 18(1), 32-43.

Svensson, M., \& Drust, B. (2005). Testing soccer players. Journal of Sports Sciences, 23(6), 601618.

Tomkinson, G. R., Carver, K. D., Atkinson, F., Daniell, N. D., Lewis, L. K., Fitzgerald, J. S., ... Ortega, F. B. (2017). European normative values for physical fitness in children and adolescents aged 9-17 years: Results from 2779165 Eurofit performances representing 30 countries. British Journal of Sports Medicine, 52(22), 1445-1456.

Tomkinson, G. R., Olds, T. S., \& Borms, J. (2007). Who are the Eurofittest ? Medical Sport Science, 50, 104-128.

Trecroci, A., Milanovic, Z., Frontini, M., laia, F. M., \& Alberti, G. (2018). Physical performance comparison between under 15 elite and sub-elite soccer players. Journal of Human Kinetics, 
61(1), 209-216.

Tuckman, B. W., \& Waheed, M. A. (1981). Evaluating an individualized science program for community college students. Journal of Research in Science Teaching, 18(6), 489-495.

Tumilty, D. (1993). Physiological characteristics of elite soccer players. Sports Medicine, 16(2), 80-96.

Turner, A., Walker, S., Stembridge, M., Coneyworth, P., Reed, G., Birdsey, L., ... Moody, J. (2011). A testing battery for the assessment of fitness in soccer players. Strength and Conditioning Journal, 33(5), 29-39.

Vaeyens, R., Malina, R. M., Janssens, M., Van Renterghem, B., Bourgois, J., Vrijens, J., \& Philippaerts, R. M. (2006). A multidisciplinary selection model for youth soccer: The Ghent youth soccer project. British Journal of Sports Medicine, 40(11), 928-934.

Vandendriessche, J. B., Vaeyens, R., Vandorpe, B., Lenoir, M., Lefevre, J., \& Philippaerts, R. M. (2012). Biological maturation, morphology, fitness, and motor coordination as part of a selection strategy in the search for international youth soccer players (age 15-16 years). Journal of Sports Sciences, 30(15), 1695-1703.

Vandorpe, B., Vandendriessche, J. B., Vaeyens, R., Pion, J., Lefevre, J., Philippaerts, R. M., \& Lenoir, M. (2012). The value of a non-sport-specific motor test battery in predicting performance in young female gymnasts. Journal of Sports Sciences, 30(5), 497-505.

Williams, A. M., \& Reilly, T. (2000). Talent identification and development in soccer. Journal of Sports Sciences, 18(9), 657-667. 